\title{
LIFE OF ST. PANCRATIUS: CLARIFICATION OF TERMS AND RECONSTRUCTION OF BOOK WRITING AND ICON PAINTING REALIA IN THE $10^{\text {th }}$ AND $11^{\text {th }}$ CENTURIES
}

\author{
Kseniia S. Morugina \\ Institute of World History of the Russian Academy of Sciences, Moscow, Russian Federation
}

\begin{abstract}
Introduction. The paper attempts to compare and analyze specific words identifying book writing and icon painting realia in the Life of St. Pancratius thereby providing new definitions for these terms. In the light of the results obtained, it became possible to propose a reconstruction of book writing and icon painting at the time described in the Life of St. Pancratius. Methods. The methodological basis of the research is the comparative analysis of various editions of the same literary work. Analysis. There was no unity among specialists involved in the translation of the Life of St. Pancratius into other languages (namely Russian and English) in conveying the meaning of certain words. This situation led to the misconception and obscurity of the historical situation with liturgical books in this text. The analysis of evidence in regards to writing materials and bookmaking has been performed via comparison of two various editions of the Life of St. Pancratius: the first edition published by C.J. Stallman and the unpublished second edition in the manuscript of GIM Vlad. 381. Results. The examination of the writing and icon-painting materials introduced in the Life of St. Pancratius was accomplished via comparison of the published first edition with the unreleased second edition. This comparison has led to uncovering new data, which adds to the historical picture - more specifically it describes on which materials the books and the icons were created in the Life of St. Pancratius.

Key words: St. Pancratius, Greek hagiography, Greek language, writing and icon painting materials, textual studies.

Citation. Morugina K.S. Life of St. Pancratius: Clarification of Terms and Reconstruction of Book Writing and Icon Painting Realia in the $10^{\text {th }}$ and $11^{\text {th }}$ Centuries. Vestnik Volgogradskogo gosudarstvennogo universiteta. Seriya 4. Istoriya. Regionovedenie. Mezhdunarodnye otnosheniya [Science Journal of Volgograd State University. History. Area Studies. International Relations], 2020, vol. 25, no. 6, pp. 243-252. (in Russian). DOI: https://doi. org/10.15688/jvolsu4.2020.6.19
\end{abstract}

УДК 94“9/10”:655+75.046

ББК 63.3(0)41-7

Дата поступления статьи: 29.06.2020

Дата принятия статьи: 25.09.2020

\section{ЖИТИЕ СВ. ПАНКРАТИЯ: К УТОЧНЕНИЮ ТЕРМИНОВ И РЕКОНСТРУКЦИИ РЕАЛИЙ КНИЖНОГО ДЕЛА И ИКОНОПИСИ В Х-XI ВЕКАХ ${ }^{1}$}

\author{
Ксения Сергеевна Моругина \\ Институт всеобщей истории РАН, г. Москва, Российская Федерация
}

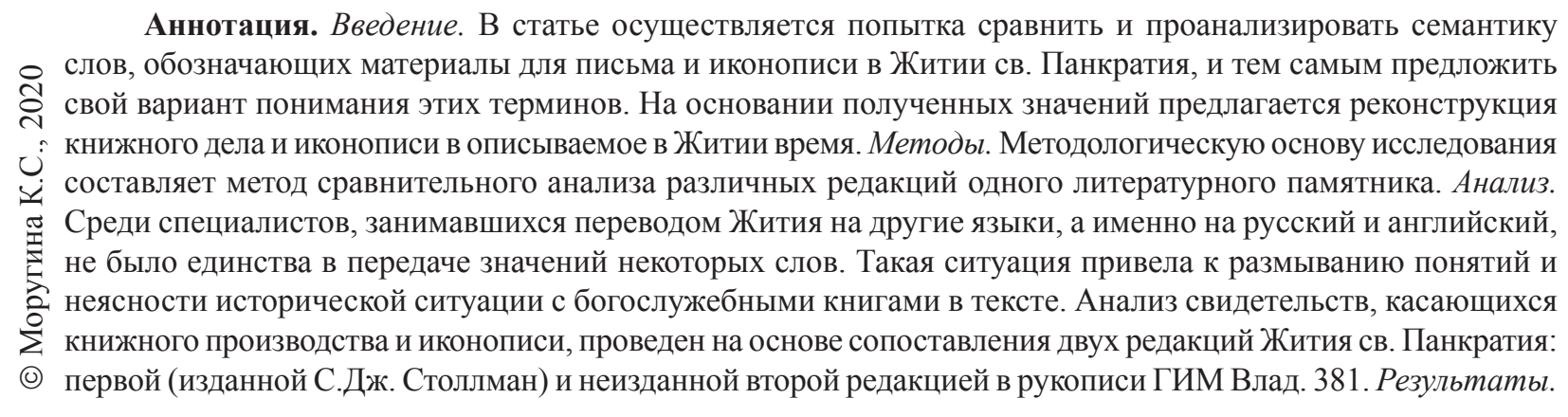




\section{ВИЗАНТИЙСКОЕ ПРАВОСЛАВИЕ}

В результате исследования значений слов, обозначающих представленные в Житии предметы для письма и иконописи, на основе новых данных, сравнив изданную первую редакцию с неизданной второй, удалось предложить иные варианты перевода, которые позволили уточнить, какой материал использовался для написания книг и как создавали иконы в Житии св. Панкратия.

Ключевые слова: св. Панкратий, греческая агиография, греческий язык, материалы для письма и иконописи, текстология.

Цитирование. Моругина К. С. Житие св. Панкратия: к уточнению терминов и реконструкции реалий книжного дела и иконописи в X-XI веках // Вестник Волгоградского государственного университета. Серия 4, История. Регионоведение. Международные отношения. - 2020. - Т. 25, № 6. - C. 243-252. - DOI: https://doi. org/10.15688/jvolsu4.2020.6.19

Введение. Исследование посвящено относительно малоизученному памятнику византийской агиографии - Житию святого Панкратия, ученика апостола Петра и епископа Тавромении [16, nos. 1410-1410m; 15, p. 155-171]. Предметом настоящего исследования являются упоминающиеся в Житии термины, обозначающие материалы для письма и иконописи. Помимо свидетельств, затрагивающих топографию, архитектуру, церковные устои, литургические обряды [30, p. 22], в Житии св. Панкратия встречается большое количество слов, обозначающих писчие и иконописные материалы и принадлежности, например «о́ ті́v $\alpha \xi » /(д о с к а), ~ « \tau \dot{\alpha}$ غ่ $\gamma \kappa \eta \varrho o ́ \tau \alpha \tau \alpha \chi \varrho \omega ́ \mu \alpha \tau \alpha » /$ (восковые краски) и

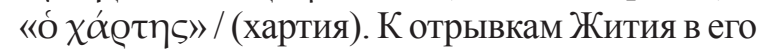
первой редакции неоднократно обращались исследователи, поскольку эти фрагменты являются редкими свидетельствами о книжном производстве, и также, возможно, являются подтверждением того, что по приказанию апостолов создавались художественные образцы, по которым расписывали церкви [24, p. 137-138]. В настоящей статье осуществляется попытка сравнить и проанализировать переводы слов такой семантики в первой и второй редакции Жития со среднегреческого на английский и русский языки.

Методы. Методологическую основу исследования составляет метод сравнительного анализа различных редакций одного литературного памятника.

Анализ. Точная дата написания Жития неизвестна, однако существуют хронологические маркеры, позволяющие считать 680 г. самой ранней, а 814 г. - самой поздней датировкой создания текста. Обе датировки были установлены С.Дж. Столлман. Самую раннюю дату создания Жития исследовательница вы- деляет благодаря употребленному в тексте топониму «Калабрия» для древнего Бруттия, использовавшемуся около 680 г. [30, р. 12], а позднейшую - основываясь на письме Феодора Студита от 814 г., в котором он цитирует текст Жития [30, p. 11]. Некоторые исследователи считают, что легенда о святом Панкратии зародилась на Сицилии, и там же создавался текст Жития, однако окончательное формирование текста произошло в Константинополе [5, с. $388-389 ; 4$, с. 117,302$]$.

В роли повествователя в Житии выступает ученик св. Панкратия Евагрий. По утверждению самого Евагрия, он сам будучи современником апостола Петра и св. Панкратия стал очевидцем распространения христианства на Сицилии. Иными словами, по утверждению автора текста Жития, он и его наставник св. Панкратий жили в I в. н. э. Однако из-за встречающегося в тексте анахронизма - упоминание об аварах (VI в.) [29, p. 20-23], можно допустить, что автор Жития не был современником описываемых событий [5, с. 388], или произведение могло дополняться в последующие века, то есть речь идет об эволюции текста на протяжении семи - восьми столетий.

Существуют три редакции Жития, которые были выделены С.Дж. Столлман [30, p. 23-25] на основе текстологического анализа: первая является наиболее ранней (X в.), вторая возникла на Афоне в XI в., а третья представлена в единственном манускрипте (XI в.) и значительно сокращена по сравнению с первой и второй [30, p. 23-25]. Таким образом, создание первой редакции текста Жития св. Панкратия, по-видимому, произошло приблизительно на двести или триста лет позже формирования текста, если придерживаться датировок С.Дж. Столлман: 680 или 
814 годы. Исследовательница отмечала, что между рукописями первой редакции имеются разночтения лингвистического и орфографического характера, однако между ними нет расхождения по содержанию или построению. Пять манускриптов второй редакции содержат лишь незначительные разночтения [30, p. 26]. Сравнивая первую редакцию со второй, Столлман отметила, что вторая редакция является сокращением и значительным стилистическим улучшением первой редакции. Вторая редакция, как и третья, не были предметом специального исследования вплоть до настоящего времени, однако уже С.Дж. Столлман отмечала важность введения всех редакций Жития св. Панкратия в научный оборот, подчеркивая перспективы дальнейшего исследования второй редакции [30, p. 27]. Неизданная вторая редакция, к которой мы обратились в рамках нашего исследования, сохранилась в аутентичной рукописи под шифром ГИМ Влад. 381 [2, с. $574 ; 7$, с. 125], созданной в 1023 г. в Ивирском монастыре на Афоне каллиграфом Феофаном Ивиритом [20, p. 42, 57]. Анализ свидетельств, касающихся книжного производства и иконописи исследуемой эпохи, проведен нами на основе сопоставления двух редакций Жития св. Панкратия: первой (изданной С.Дж. Столлман) и неизданной второй редакцией в рукописи ГИМ Влад. 381.

История переводов Жития св. Панкратия на современные языки начинается с 1986 г., когда С.Дж. Столлман в отдельной главе диссертации, посвященной вопросу создания изображений и декорированию церквей в раннюю апостольскую эпоху, рассмотрела некоторые аспекты Жития и в том числе перевела некоторые термины с греческого на английский язык [31, p. 136-156]. Ключевым моментом исследования Жития св. Панкратия стала диссертация С.Дж. Столлман. Полный перевод греческого текста Жития в его первой редакции на английский язык впервые был выполнен в 2018 г. группой австралийских исследователей под руководством Дж.Б. Берка в издании «The Life of S. Pancratius of Taormina» [30], представляющем собой диссертацию С.Дж. Столлман, которую сама исследовательница не успела опубликовать при жизни. С. Мэнго в 1986 г. в фундаментальном труде по истории византийского искусства в перечень искусствоведческих текстов также включил фрагменты Жития св. Панкратия, содержащие упоминания иконописных материалов, сопроводив их переводом на английский язык [24, p. 137-138]. Изучая вопрос о миссионерской деятельности в Византии, И. Шевченко в статье 1999 г. опубликовал отрывки на греческом языке, содержащие упоминания о писчих материалах, с переводом на русский [9, p. 317-322]. Среди перечисленных выше специалистов, занимавшихся переводом Жития на другие языки, а именно русский и английский, не было единства в передаче значения некоторых слов.

Прежде чем перейти к анализу контекстов Жития, следует сказать несколько слов о различии двух редакций, и тем самым обосновать обращение ко второй редакции, как необходимой для уточнения терминологии. Между первой и второй редакцией текста Жития св. Панкратия имеются значительные разночтения как в композиционном, так и лингвистическом плане. Вариант текста Жития, представленный в ГИМ Влад. 381, как представляется, был подвергнут литературной обработке. К такому выводу можно прийти, приняв во внимание значительные сокращения текста, с выбросом «ненужных» на взгляд средневекового редактора фрагментов, а также употребление плюсквамперфекта вместо перфекта во многих случаях и другие подобные приемы. Также обращает на себя внимание выбор лица и числа в повествовании: как правило, в первой редакции чаще встречается форма «ү் (мы), в то время как во второй - «غ่ү $\dot{» ~ / ~(я) . ~}$ Например, на л. 122 рукописи второй редакции

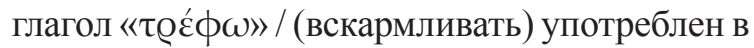

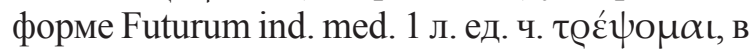
первой редакции - Praesens con. act. 1 л. мн. ч. $\tau \varrho \varepsilon ́ \psi \omega \mu \varepsilon v$ и т. п. Также имеются разночтения при употреблении имен собственных. Например, в первой редакции название города Иеру-

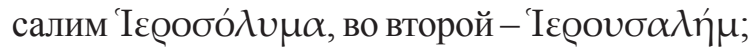
имя мужа, рукоположенного апостолом Петром в епископы, в первой редакции М'́́

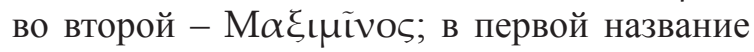

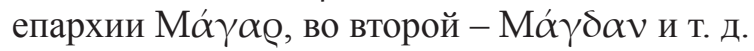
В некоторых случаях фрагменты текста первой редакции сокращены, в то время как те же фрагменты второй редакции, наоборот, расширены. Это можно констатировать на примере 
фрагмента на л. 146-146 об. (ГИМ Влад. 381), в котором исключительно детально, по сравнению с первой редакцией, приводится эпизод распятия Христа. В таких случаях вторая редакция уточняет или дополняет текст первой редакции. Обращение ко второй редакции текста позволило скорректировать значение некоторых терминов, семантика которых в первой редакции была не столь определенной.

Для анализа было выделено несколько фрагментов, содержащих упоминания о писчих и иконописных материалах. В конце л. 125-125 об. рукописи ГИМ Влад. 381 содержится отрывок, описывающий распоряжение апостола Петра, адресуемое живописцу Иоси$\phi y$. Апостол просит Иосифа нарисовать икону

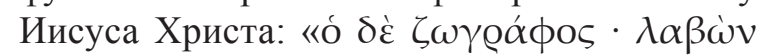

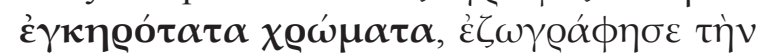

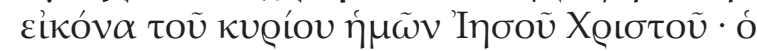

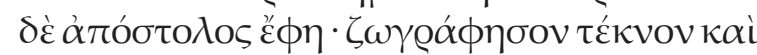

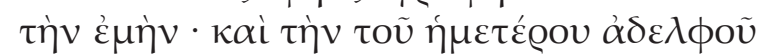

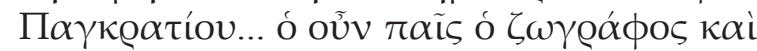

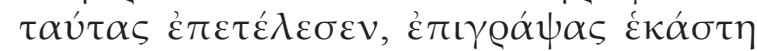

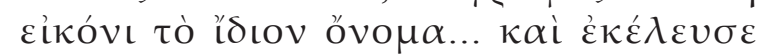

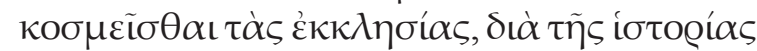

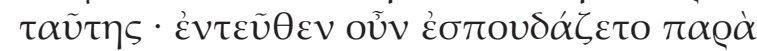

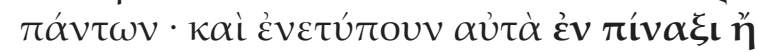

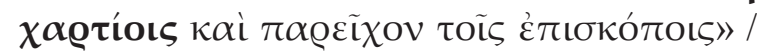
(живописец же, взяв восковые краски, написал икону Господа нашего Иисуса Христа. Апостол же сказал ему: «Чадо, напиши и мою икону, и икону брата нашего Панкратия»... Итак, раб-живописец закончил эти иконы и надписал на каждой соответствующее название... И повелел Петр расписать церкви согласно этой истории, из которой все узнавали о Нем. Переносили они сюжет на доски или папирус и передавали епископам).

Из приведенного отрывка следует, что для написания икон художник использует

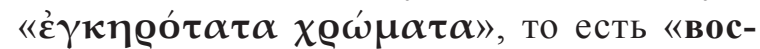
ковые краски». Этот технологический прием состоял в том, что художник перед нанесением вмешивал пигменты в восковую эмульсию, надежно защищающую в основном деревянные поверхности от внешних факторов [38, p. 627]. У Анастасия Синаита, жившего около 640 г. до начала VIII в. [11, S. 442-446], то есть как раз тогда, когда происходило формирование текста Жития, в сочинении «Проповедь о субботе» (Sermo de sabbato) описывается по- добный принцип смешения красок: «Еı̉кóvos

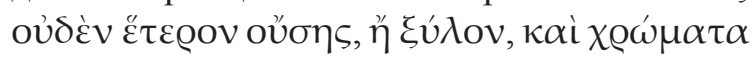

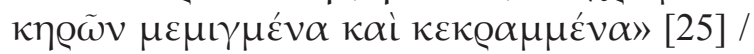
(Икона есть не что иное, как дерево и краски, при помощи воска смешанные и хорошо пере-

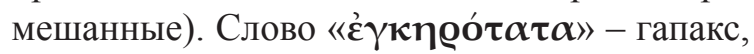
встречается только в Житии св. Панкратия [22; 34]. В первой редакции в том же фрагменте использована другая формулировка:

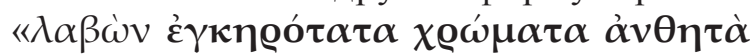

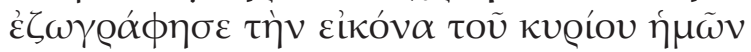

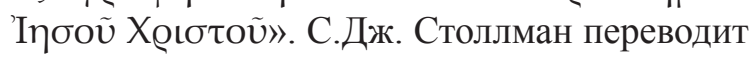
такое сочетание как «энкаустические краски», то есть состоящие из подогретого расплавленного воска, смол, масла (кедровое, льняное, ореховое, хлопковое) и большого количества пигмента [8, с. 47]. В качестве пигментов могли использоваться: свинцовые белила, мел, кость черная, сажа газовая, киноварь красная, понтийская красная, кармин фиолетовый, кармин красный, сурик желтый, охра светлая, охра красная, охра темная, эфесская желтая, мумия красно-коричневая, сепия (коричневая), терраде-сиена (коричневая), ляпис-лазурь, египетская синяя, искусственная зеленая (медянка)

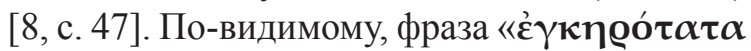

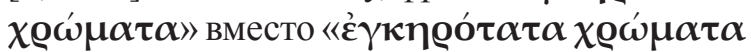
$\dot{\alpha} v \theta \eta \tau \dot{\alpha} »$ означает, что во второй редакции Жития подразумевается техника восковой темперы, отличающейся от энкаустики яркостью красок. Можно предположить, что составители второй редакции Жития, вышедшей на столетие позже первой редакции, решили

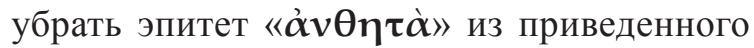
фрагмента, поскольку начиная с IX в. техника исполненной кистью и красками иконы на доске - темпера [10, с. 31-39]. Темпера была дешевле, и процесс работы с ней проще, что может объяснять преобладание такого метода в дальнейшем [8, с. 14-15].

В этом же отрывке особый интерес

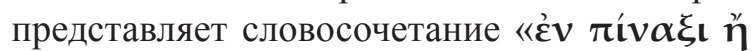

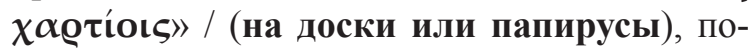
скольку в первой редакции исследуемая фраза

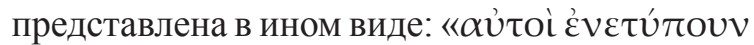

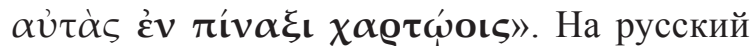
язык И. Шевченко переводит сочетание «в̇v

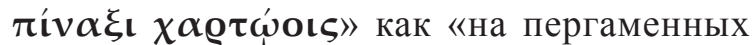
листах», Дж. Б. Берк - «papyrus pages» [30, p. 55]. С.Дж. Столлман в разделе диссертации, посвященном изучению создания изображе- 
ний и декорированию церквей, указывает: «A recurring feature of the VP is a book consisting of a number of papyrus leaves illustrated with scenes from Scripture» [31, p. 136] / (Периодически встречающийся элемент в Житии св. Панкратия - книга, состоящая из папирусных листов со сценами из Писания). То есть она, во-первых, указывает на то, что речь идет о книге, а во-вторых, обозначает писчий материал этой книги как «папирусные листы», a не «пергаменные листы», как перевел это словосочетание И. Шевченко [9, p. 318].

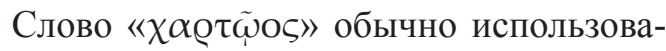
лось для обозначения бумаги [22, p. 1716, s.v.

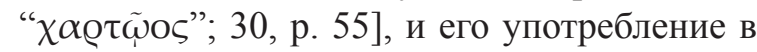
данном контексте вынуждает датировать текст Жития периодом после VIII в., когда бумага была принесена в Византию через арабов [3, c. 23]. Однако приведенное слово употреблялось и для обозначения папирусных рукописей на Соборе 680 года [25, 11: 588E-589D; 13, p. 1-15; 35, p. 329-330]. Папирус, после того как его вытеснил пергамен на большинстве территорий, продолжал использоваться на Сицилии и в Египте [36, p. 1-8; 32, p. 18, 102-103, 265-266, 590]. Основным центром производства папируса оставались Сиракузы [36, p. 1-8; 32, p. 5]. Сицилия являлась главным поставщиком папируса для папской канцелярии, которая использовала папирус вплоть до $\mathrm{XI}$ в. [14, p. 10; 28, S. 32-52], и для скрипториев в Равенне, где папирус применялся для производства рукописей до Х в. [28, S. 56-61; 32, p. 5].

На наш взгляд, более подходящим вариантом перевода для словосочетания « $\pi \dot{\imath} v \alpha \xi$ $\chi \alpha \varrho \tau \omega$ оı » было бы «папирусные кодексы», поскольку в мировой литературе, особенно в еврейской (например, в трактате Келим Мишны, в главе 24 строке 7, где упоминается три типа «ті́v $\alpha \kappa \varepsilon \varsigma »:$ из папируса, с обработанной воском поверхностью и с полированной по-

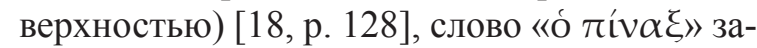
частую тождественно по смыслу слову «сodex»

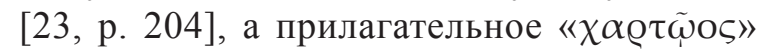

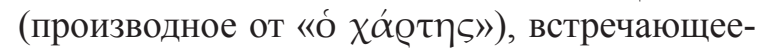
ся довольно редко, в первом значении переводится как «папирусный», и только позже приобрело смысл «сделанный из бумаги» [22,

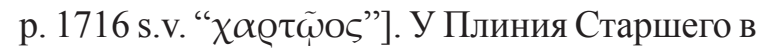
его «Естественной истории» [27 (XIII, 74-82)] для обозначения папируса используется слово

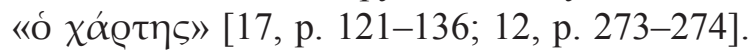
Словосочетание «папирусный кодекс» не является редкостью: у Кассиодора между 551 и 562 гг. в сочинении «Institutiones divinarum et saecularium litterarum» [21, S. 278-279] встречается упоминание «codex chartaceus» в значении папирусного кодекса, содержащего текст Библии [1, с. 108]. Как явствует из дальнейшего прочтения Жития, каждый раз, когда Панкратий готовится сокрушать идолов, он просит Евагрия принести «орудия веры», перечень которых включает в себя «честной и животворящий крест, святые евангелия, иконы Иисуса Христа и апостола Петра, а также кафолические послания апостола Пе-

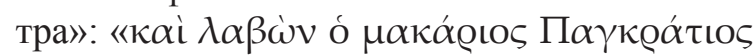

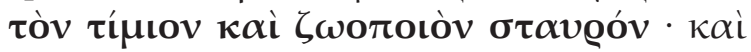

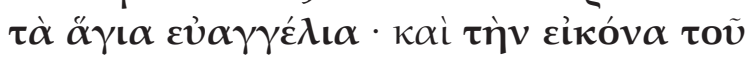

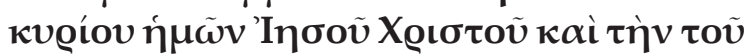

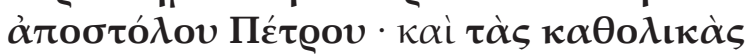

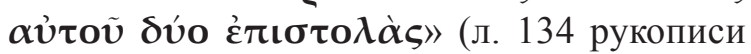
ГИМ Влад. 381). Крест св. Панкратий устанавливает на земле, рядом с ним просит встать Евагрия с иконами в руках, а сам приближается к идолу. При этом святые евангелия и послания апостола Петра должны находиться у него, так как руки Евагрия заняты иконами, а поместить священные книги на землю было бы кощунством. Если учесть, что Панкратий должен осенять идолов крестным знаменем, одна рука у него должна быть свободна. Более того, во время ритуала сокрушения идолов поднимается ветер, и удержать одной рукой разрозненные листы представляется невозможным. В свободной руке у Панкратия, повидимому, должна была быть книга в форме кодекса.

В греческом языке словосочетание

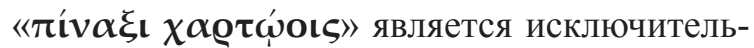
но редким и встречается только в Житии св. Панкратия.

В Thesaurus Linguae Graecae [33] был осуществлен поиск словосочетания «ті́v $\alpha \kappa \varepsilon \varsigma$

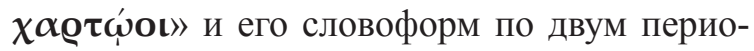
дам греческого языка (древнегреческий язык (XIV в. до н. э. - IV в. н. э.) и греческий язык византийского периода ( $\mathrm{V}-\mathrm{XV}$ вв.)). Выявить удалось только два случая употребления данного оборота, представляющие собой дословные выдержки из Жития св. Панкратия в 


\section{ВИЗАНТИЙСКОЕ ПРАВОСЛАВИЕ}

его первой редакции. Искомое словосочетание встретилось в сочинении константинопольского патриарха Никифора (ок. 758-828) «Обличение и опровержения безбожного и нечестивого определения собора, бывшего в 815 г.» (Nicephori Patriarchae Constantinopolitani Refutatio et eversio definitionis synodalis anni

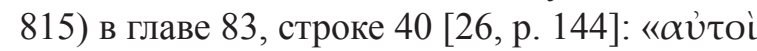

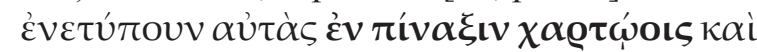

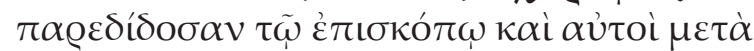

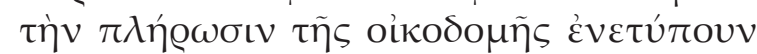
$\alpha \hat{v} \tau \alpha \dot{\varsigma} »$. В том числе в главе 83 , строке 83

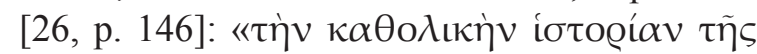

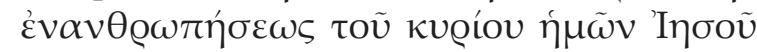
Х $\chi \alpha \varrho \tau \omega$ о เ૬». Можно сделать вывод, что патриарх Никифор в 820 г. при написании своего «Refutatio et Eversio», как и Феодор Студит в своем письме от 814 г. [29, p. 11], пользовались не дошедшей до нас рукописью, послужившей прототипом для первой редакции Жития св. Панкратия. Патриарх Никифор указывает, что кодекс, из которого он берет отрывки Жи-

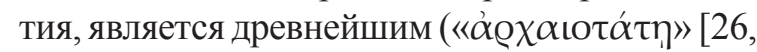
p. 148]), и отмечает искажение текста Жития со стороны иконоборцев [26, p. 147-150]. Повидимому, рукопись-прототип, из которой патриарх Никифор выписывал отрывки для своего сочинения в разгар второй волны иконоборчества, в 820 г. находилась в монастыре во имя мч. Феодора близ Хрисополя (ныне Ускюдар, Турция) - место ссылки патриарха Никифора с 815 г. до его смерти в 829 г. [6, c. 724-725]. Поскольку патриарху для дословного цитирования отрывков, полностью совпадающих с отрывками первой редакции, при написании своего сочинения нужно было иметь первоисточник при себе. Отмечая искажение текста Жития со стороны иконоборцев, патриарх Никифор подразумевает текст, который в дальнейшем послужит прототипом первой редакции Жития. Возможно, рукопись первой редакции - Vat. Gr. 1591 (964 г.) была сделана непосредственно с того самого не дошедшего до нас прототипа. Вторая редакция, возникшая в XI в. и несущая в себе очевидные признаки литературной обработки, представляет собой окончательный результат корректировок афонских монахов (иконопочитателей), восстановивших текст максимально близко к исходному варианту.
Слово «о́ $\pi \dot{\imath} v \alpha \xi »[22$, p. 1214, s.v. “ $\pi \dot{v} v \alpha \xi ”]$ во второй редакции встречается 6 раз (на л. 125 об., 132 об., 146, 146 об., 173, $175)$, в то время как в первой редакции -5 раз. И. Шевченко делает оговорку, что переводит термин «ті́v $\alpha \xi »$ по-разному: как «листы» или «картинки» $[9$, р. 318$]$ и добавляет, что «из контекста ясно, что ті́́v $\alpha \kappa \varepsilon \varsigma$ Жития - не доски или таблицы, а картинки или рисунки, изображенные на отдельных листах или свитках пергамена» [9, p. 318]. Можно лишь частично согласиться с точностью такого перевода, поскольку в отличие от приведенного выше неясного места, в других контекстах Жития слово «ті́v $\alpha \xi »$ употреблено в своем основном значении. Например,

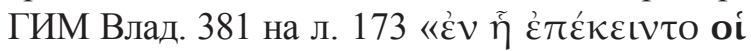

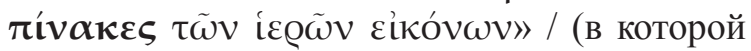
лежали доски святых икон) и на л. $175 \ll \dot{\alpha} \lambda \lambda \dot{\alpha}$

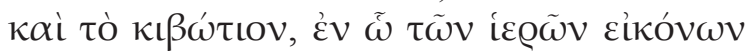

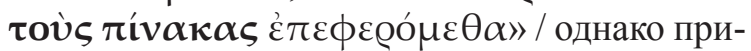
носили мы и ковчежец, в котором были доски святых икон). Другой исследователь, С. Мэнго, переводит это же слово как «panels» или «pictures» [24, p. 137-138].

На л. 132 об. рукописи ГИМ Влад. 381 фрагмент с упоминанием «ті́v $\alpha \kappa \varepsilon \varsigma »: ~ « \kappa \alpha i ~$

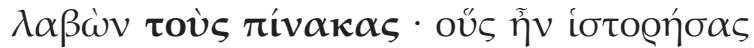

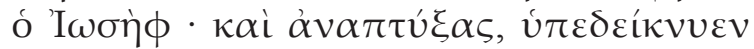
$\alpha \hat{v} \tau о \tilde{\iota} \varsigma » /($ взяв и разложив доски, которые расписал Иосиф, он показывал их им).

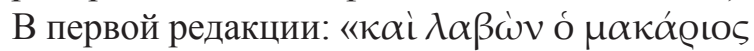

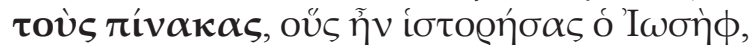
$\dot{\alpha} v \alpha \pi \tau \dot{v} \xi \alpha \varsigma, \dot{v} \pi \varepsilon \dot{\delta} \delta \varepsilon \xi \xi \varepsilon \alpha \hat{v} \tau о \tilde{\iota} \varsigma »$. В переводе

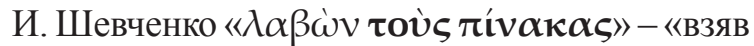
картинки», в переводе Дж. Б. Берка - «took the pages». На наш взгляд, из контекста следует, что речь идет именно о досках с изображениями, поскольку их приходилось раскладывать перед смотрящими.

Ниже, на л. 146-146 об. рукописи ГИМ

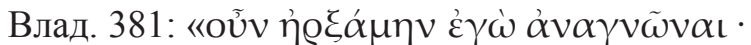

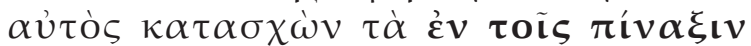

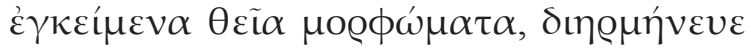

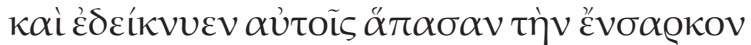

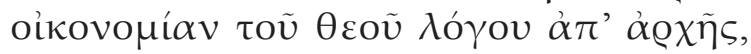

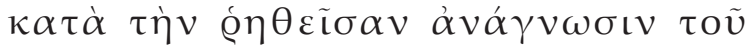

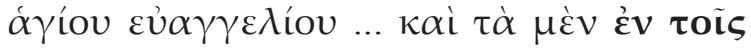

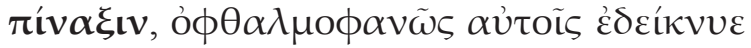

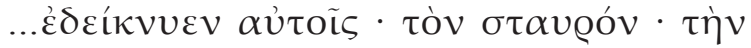

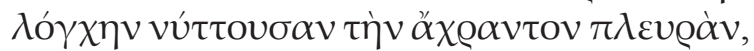

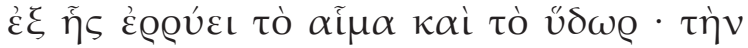


$\tau \alpha \phi \eta ́ v \cdot \tau \eta ̀ v ~ \alpha v \alpha ́ \sigma \tau \alpha \sigma \iota v » /$ (затем, когда я начал читать, он, держа при себе божественные образы, запечатленные на досках, толковал и показывал им все домостроительство воплощения Бога Слова с самого начала, согласно читаемому вслух тексту Святого Евангелия... он наглядно показывал им все, что было на досках... он показывал им Распятие [19, р. 45-47], копье, пронзившее пречистое ребро, из которого истекла кровь и вода, погребение и Воскресение). В первой редакции выбранный фраг-

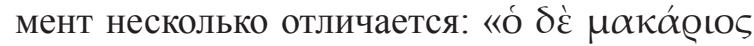

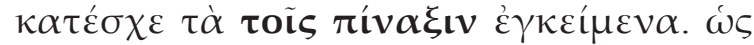

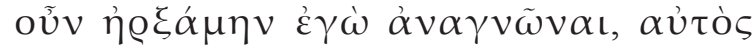

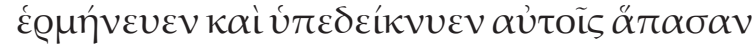

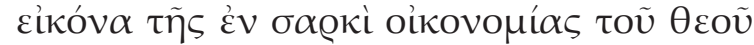

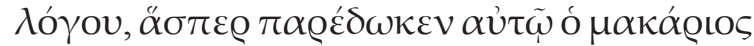

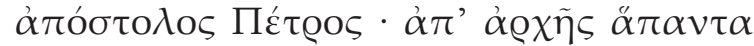

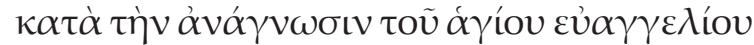

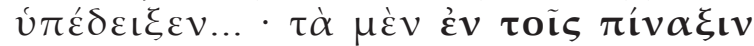
ú $\pi \dot{\varepsilon} \delta \varepsilon \iota \xi \varepsilon, \tau \dot{\alpha} \varsigma \delta \dot{\varepsilon} \pi \alpha \varrho \alpha \beta \mathrm{o} \lambda \dot{\alpha} \varsigma \delta \iota \varepsilon Q \mu \eta ́ v \varepsilon v \sigma \varepsilon v$

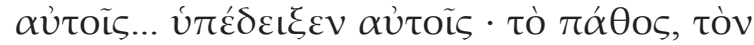

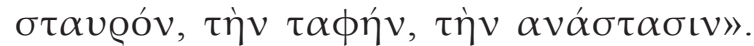
В данном контексте Дж.Б. Берк предлагает

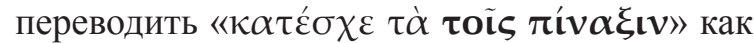

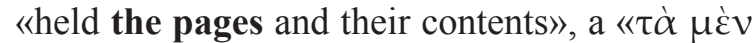

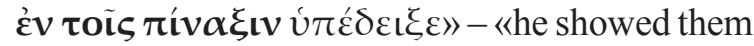
what was on the pages» [30, p. 139], в то время как перевод И. Шевченко - «удержал при себе то, что было на картинках» и «все это он показал на картинках» [9, р. 321] соответственно. В данном случае, как и в предыдущих отрывках Жития св. Панкратия, между учеными нет единства в передаче значения слова «ті́v $\alpha \xi »$. Упоминание в отрывках и первой и второй редакций сюжета Распятия говорит в пользу того, что текст Жития не мог быть оформлен ранее конца VII в., поскольку именно так датируется самое раннее упоминание о репрезентации Христа, умершего на кресте, в сочинении Анастасия Синаита [19, p. 40-57]. Самое раннее наглядное свидетельство переносная икона с горы Синай - датируется началом - серединой VIII в. [37, р. 61-64; 19, p. 67-68]. Евагрий подразумевает, что все упоминаемые им сцены содержатся в иллюстрированном руководстве, но неясно, было ли Евангелие источником для этого списка или источником послужила конкретная, известная Евагрию, схема декорирования церкви [30, p. 14-15].
Результаты. В заключение следует отметить, что наше современное понимание специальных слов и выражений, встречающихся в изобилии в агиографических текстах, не всегда предполагает абсолютную определенность и однозначность. В частности, в Житии св. Панкратия встречается большое количество слов, обозначающих материалы для письма и иконописи. Некоторые исследователи обозначали материал книг, упомянутых в Житии, как папирус, другие - как пергамен. Одни исследователи считали, что Панкратий раскладывал перед новообращенными листы или картинки, переводя таким образом слово «ті́v $\alpha \kappa \varepsilon \varsigma » /$ (доски). В результате нашего исследования представленных в Житии св. Панкратия слов выбранной семантики, на основе новых данных (сравнив изданную первую редакцию с неизданной второй) можно предложить иное понимание смысла следующих понятий:

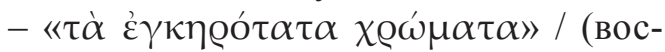
ковые краски) - вместо ранее предложенного исследователями варианта перевода «encaustic paints», «энкаустические краски»;

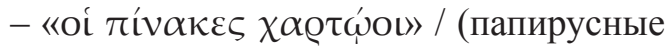
кодексы) - вместо «раpyrus pages», «papyrus leaves», «пергаменные листы»;

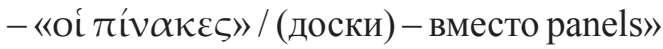
или «pictures», «листы» или «картинки»;

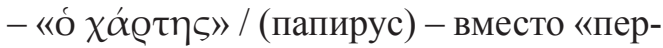
гамен».

Согласно тексту «Жития св. Панкратия», он как миссионер раскладывал выполненные на досках восковыми красками изображения перед прозелитами, параллельно читая вслух папирусные кодексы, содержащие ветхо- и новозаветные пассажи.

\section{ПРИМЕЧАНИЕ}

${ }^{1}$ Исследование выполнено при финансовой поддержке РФФИ в рамках научного проекта № 19-39-90022.

The reported study was funded by RFBR, project number 19-39-90022.

\section{СПИСОК ЛИТЕРАТУРЫ}

1. Борухович, В. Г. В мире античных свитков / В. Г. Борухович. - Саратов : Изд-во Сарат. ун-та, 1976. - 224 c.

2. Владимир (Филантропов), архим. Систематическое описание рукописей Московской Сино- 
дальной (Патриаршей) библиотеки. Ч. 1 : Рукописи греческие / архим. Владимир (Филантропов). - М. : Синодальная типография, 1894. - 880 с.

3. Гийу, А. Византийская цивилизация / А. Гийу.Екатеринбург : У-Фактория, 2005. - 552 с.

4. Иванов, С. А. Византийское миссионерство : Можно ли сделать из «варвара» христианина? / С. А. Иванов. - М. : Языки славянской культуры, 2003. $-376 \mathrm{c}$.

5. Каждан, А. П. История византийской литературы (650-850 гг.) / А. П. Каждан. - СПб. : Алетейя, 2002. - 530 с.

6. Луховицкий, Л. В. Никифор Константинопольский / Л. В. Луховицкий // Большая российская энциклопедия. - 2013. - Т. 22. - С. 724-725.

7. Фонкич, Б. Л. Греческие рукописи Московской Синодальной библиотеки. Палеографические, кодикологические и библиографические дополнения к каталогу архимандрита Владимира (Филантропова) / Б. Л. Фонкич, Ф. Б. Поляков. М. : Синодальная библиотека, 1993. - 228 с.

8. Хвостенко, Т. В. Энкаустика. Искусство, пережившее тысячелетия / Т. В. Хвостенко. - М. : Советский художник, 1985. - 160 с.

9. Шевченко, И. Оснащение византийского миссионера по Житию Панкратия / И. Шевченко // Paleoslavica. - 1999. - Vol. 7. - Р. 317-322.

10. Яковлева, А. И. Техника иконы / А. И. Яковлева // История иконописи, VI-XX вв. : Истоки, традиции, современность / под ред. Т. В. Моисеевой. - М. : Арт-БМБ, 2002. - С. 29-40.

11. Beck, H. G. Kirche und theologische Literatur im byzantinischen Reich / H. G. Beck. - München : C. H. Beck, 1977. -835 S.

12. Bülow-Jacobsen, A. «Magna in latitudine earum differentia» (Pliny, NH XIII, 78) / A. BülowJacobsen // Zeitschrift für Papyrologie und Epigraphik. 1985. - Vol. 60. - P. 273-274.

13. Devreesse, R. Le cinquième concile et l'œcuménicité byzantine / R. Devreesse // Miscellanea Giovanni Mercati. - 1946. - Vol. III. - P. 1-15.

14. Devreesse, R. Introduction à l'étude des manuscrits grecs / R. Devreesse. - Paris : Imprimerie Nationale, 1954. - 348 p.

15. Esbroeck M., van. Le dossier hagiographique de S. Pancrace de Taormine / M. van Esbroeck, U. Zanetti // Storia della Sicilia e tradizione agiografica nella tarda antichità / a cura di S. Pricoco. - Soveria Mannelli : Rubbettino, 1988. - P. 155-171.

16. Halkin, F. Bibliotheca hagiographica Graeca / F. Halkin. -3 ed. - Bruxelles : ed. Socii Bollandiani, 1957. $-351 \mathrm{p}$.

17. Hendriks, I. H. M. Pliny, Historia Naturalis XIII, 74-82 and the Manufacture of Papyrus / I. H. M. Hendriks // Zeitschrift für Papyrologie und Epigraphik. - 1980. - Vol. 37. - P. 121-136.
18. Hezser, C. Jewish Literacy in Roman Palestine / C. Hezser. - Tübingen : Mohr Siebeck, 2001. $557 \mathrm{p}$.

19. Kartsonis, A. D. Anastasis : The Making of an Image / A. D. Kartsonis. - Princeton : Princeton University Press, 1986. -263 p.

20. Lefort, J. Actes d'Iviron. Des origines au milieu du XIe siècle. Vol. 1 / J. Lefort, H. Métrévéli. Paris : P. Lethielleux, 1985. -318 p.

21. Lehmann, P. Cassiodorstudien / P. Lehmann // Philologus. - 1912. - Vol. 71. - S. 278-279.

22. Liddell, H. G. A Greek-English Lexicon / H. G. Liddell, R. Scott, H. S. Jones, R. McKenzie. Oxford : Clarendon Press, 1940. - 2448 p.

23. Lieberman, S. Hellenism in Jewish Palestine : Studies in the Literary Transmission Beliefs and Manners of Palestine in the I Century B.C.E. IV Century C.E. / S. Lieberman. - N. Y. : Jewish Theological Seminary of America, 1962. - 231 p.

24. Mango, C. A. The Art of the Byzantine Empire, 312-1453 / C. A. Mango. - Toronto ; Buffalo ; London : University of Toronto Press, 1986. - 272 p.

25. Mansi, J. D. Sacrorum Conciliorum Nova Amplissima Collectio. Vol. 12 / J. D. Mansi // Documenta Catholica Omnia : Cooperatorum Veritatis Societas. - 2006. - Electronic text date. Mode of access: http://www.documentacatholicaomnia. eu/01_50_1692-1769-_Mansi_JD.html (date of access: 13.03.2020). - Title from screen.

26. Nicephori Patriarchae Constantinopolitani Refutatio et Eversio Definitionis Synodalis anno 815 / ed. by J. M. Featherstone. - Turnhout ; Leuven : Brepols ; University Press, 1997. - 380 p.

27. Pliny the Elder. Naturalis Historia / ed. by K. F. T. Mayhoff. - Lipsiae : Teubner, 1906. - 462 p.

28. Santifaller, L. Beiträge zur Geschichte der Beschreibstoffe im Mittelalter : Mit besonderer Berücksichtigung derpäpstlichen Kanzlei:Untersuchungen / L. Santifaller. - Graz; Köln : Hermann Böhlaus, 1953.220 S. - (Mitteilungen des Instituts für Österreichische Geschichtsforschung; 16).

29. Ševčenko, I. Religious Missions Seen From Byzantium / I. Ševčenko // Ukraine Between East and West. Essays on Cultural History to the Early Eighteenth Century / ed. by I. Ševčenko, F. E. Sysyn. Edmonton : CIUS Press, an imprint of University of Alberta Press, 1996. - P. 7-27.

30. Stallman-Pacitti, C. J. The Life of S. Pancratius of Taormina / C. J. Stallman-Pacitti. - Leiden : Brill, 2018. -525 p.

31. The Life of S. Pancratius of Taormina. Vol. I. Text / ed. by C. J. Stallman. - Oxford : University of Oxford, 1986. $-524 \mathrm{p}$.

32. The Oxford Handbook of Papyrology / ed. R. S. Bagnall. - Oxford; New York : Oxford University Press, 2009. -688 p. 
33. Thesaurus linguae graecae. Canon of Greek Authors and Works : TLG CD-ROM \# C. - Irvine : University of California, 1999. - 1 CD-ROM.

34. Trapp, E. Lexikon zur byzantinischen Gräzität besonders des 9.-12. Jahrhunderts / E. Trapp. - Wien : ÖAW, 1994. - $2060 \mathrm{~S}$.

35. Ven P., van den. La patristique et l'hagiographie au concile de Nicée de 787 / P. van den Ven // Byzantion.1957. - Vol. 25. - P. 325-362.

36. Wallert, A. The Reconstruction of Papyrus Manufacture : A Preliminary Investigation / A. Wallert // Studies in Conservation. - 1989. - Vol. 34. P. 1-8.

37. Weitzmann, K. The Monastery of St. Catherine at Mount Sinai : The Icons. From the Sixth to the Tenth Century / K. Weitzmann. - Princeton : Princeton University Press, 1976. - 107 p.

38. Wessel, K. Reallexikon zur byzantinischen Kunst / K. Wessel, M. Restle. - Stuttgart : Anton Hiersemann Publ., 1971. - 671 p.

\section{REFERENCES}

1. Borukhovich V.G. V mire antichnykh svitkov [In the World of Ancient Scrolls]. Saratov, Izd-vo Sarat. un-ta Publ., 1976. 224 p.

2. Vladimir(Filantropov), arkhim. Sistematicheskoe opisanie rukopisey Moskovskoy Sinodalnoy (Patriarshey) biblioteki. Ch. 1: Rukopisi grecheskie [Systematic Description of the Manuscripts of the Moscow Synodal Library. Chapter 1: Greek Manuscripts]. Moscow, Sinodalnaya Typographiya Publ., 1894. 880 p.

3. Giyyu A. Vizantiyskaya tsivilizatsiya [Byzantine Civilization]. Ekaterinburg, U-Faktoriya Publ., 2005. 552 p.

4. Ivanov S.A. Vizantiyskoe missionerstvo: Mozhno li sdelat iz "varvara" khristianina? [Byzantine Missionary Activity: Is It Possible to Make a Christian out of a "Barbarian"?]. Moscow, Yazyki slavyanskoy kultury Publ., 2003. 376 p.

5. Kazhdan A.P. Istoriya vizantiyskoy literatury (650-850 gg.) [The History of Byzantine Literature (650-850)]. Saint Petersburg, Aletheia Publ., 2002. $530 \mathrm{p}$.

6. Lukhovitskiy L.V. Nikifor Konstantinopolskiy. [Nicephorus of Constantinople]. Bolshaya rossiyskaya entsiklopediya [The Great Russian Encyclopedia], 2013, vol. 22, pp. 724-725.

7. FonkichB.L.,PolyakovF.B. Grecheskierukopisi Moskovskoy Sinodalnoy biblioteki. Paleograficheskie, kodikologicheskie i bibliograficheskie dopolneniya k katalogu arkhimandrita Vladimira (Filantropova) [Greek Manuscripts of the Moscow Synodal Library. Paleographical, Codicological and Bibliographical Additions to the Catalog of Archimandrite Vladimir]. Moscow, Sinodalnaya biblioteka Publ., 1993. 228 p.
8. Khvostenko T.V. Enkaustika. Iskusstvo, perezhivshee tysyacheletiya [Encaustic Painting. The Art Survived in Centuries]. Moscow, Sovetskiy khudozhnik Publ., 1985. 160 p.

9. Shevchenko I. Osnashchenie vizantiyskogo missionera po Zhitiyu Pankratiya [Equipment of a Byzantine Missioner According to the Life of St. Pancratius]. Paleoslavica, 1999, vol. 7, pp. 317-322.

10. Yakovleva A.I. Tekhnika ikony [A technique of icon]. Moiseeva T.V., ed. Istoriya ikonopisi, VI$X X v v$.: Istoki, traditsii, sovremennost [The History of Icon-Painting, from $6^{\text {th }}$ to $20^{\text {th }}$ Century: Beginnings, Traditions, Modernity]. Moscow, Art-BMB Publ., 2002, pp. 31-39.

11. Beck H.G. Kirche und theologische Literatur im byzantinischen Reich. München, C.H. Beck, 1977. $835 \mathrm{p}$.

12. Bülow-Jacobsen A. «Magna in latitudine earum differentia» (Pliny, NH XIII, 78). Zeitschrift für Papyrologie und Epigraphik, 1985, vol. 60, pp. 273-274.

13. Devreesse R. Le cinquième concile et l'œcuménicité byzantine. Miscellanea Giovanni Mercati, 1946, vol. III, pp. 1-15.

14. Devreesse R. Introduction à l'étude des manuscrits grecs. Paris, Imprimerie Nationale, 1954. 348 p.

15. Esbroeck M. van, Zanetti U. Le dossier hagiographique de S. Pancrace de Taormine. S. Pricoco, ed. Storia della Sicilia e tradizione agiografica nella tarda antichità. Soveria Mannelli, Rubbettino, 1988, pp. 155-171.

16. Halkin F. Bibliotheca hagiographica Graeca. 3 ed. Bruxelles, ed. Socii Bollandiani, 1957. 351 p.

17. Hendriks I.H.M. Pliny, Historia Naturalis XIII, 74-82 and the Manufacture of Papyrus. Zeitschrift für Papyrologie und Epigraphik, 1980, vol. 37, pp. 121-136.

18. Hezser C. Jewish Literacy in Roman Palestine. Tübingen, Mohr Siebeck, 2001. 557 p.

19. Kartsonis A.D. Anastasis: The Making of an Image. Princeton, Princeton University Press, 1986. $263 \mathrm{p}$.

20. Lefort J., Métrévéli H. Actes d'Iviron. Des origines au milieu du XI siècle. Vol. 1. Paris, P. Lethielleux, 1985. 318 p.

21. Lehmann P. Cassiodorstudien. Philologus, 1912, vol. 71, pp. 278-279.

22. Liddell H.G., Scott R., Jones H.S., McKenzie R. A Greek-English Lexicon. Oxford, Clarendon Press, 1940. 2448 p.

23. Lieberman S. Hellenism in Jewish Palestine: Studies in the Literary Transmission Beliefs and Manners of Palestine in the I Century B.C.E. IV Century C.E. N. Y., Jewish Theological Seminary of America, 1962. $231 \mathrm{p}$.

24. Mango C.A. The Art of the Byzantine Empire, 312-1453. Toronto; Buffalo; London, University of Toronto Press, 1986. 272 p. 
25. Mansi J.D. Sacrorum Conciliorum Nova Amplissima Collectio. Vol. 12. Documenta Catholica Omnia: Cooperatorum Veritatis Societas. URL: http:// www.documentacatholicaomnia.eu/01_50_16921769-_Mansi_JD.html (accessed 13.03.2020).

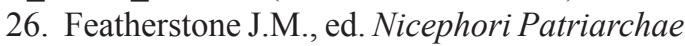
Constantinopolitani Refutatio et Eversio Definitionis Synodalis anno 815. Turnhout; Leuven, Brepols, University Press, 1997. 380 p.

27. Mayhoff K.F.T., ed. Pliny the Elder. Naturalis Historia. Lipsiae, Teubner, 1906. 462 p.

28. Santifaller L. Beiträge zur Geschichte der Beschreibstoffe im Mittelalter: mit besonderer Berücksichtigung der päpstlichen Kanzlei: Untersuchungen. Graz; Köln, Hermann Böhlaus, 1953. 220 p. (Mitteilungen des Instituts für Österreichische Geschichtsforschung; vol. 16).

29. Ševčenko I. Religious Missions Seen From Byzantium. Ševčenko I., Sysyn F. E., eds. Ukraine Between East and West. Essays on Cultural History to the Early Eighteenth Century. Edmonton, CIUS Press, an imprint of University of Alberta Press, 1996, pp. 7-27.

30. Stallman-Pacitti C. J. The Life of S. Pancratius of Taormina. Leiden, Brill, 2018. 525 p.
31. Stallman C.J., ed. The Life of S. Pancratius of Taormina. Vol. I. Text. Oxford, University of Oxford, 1986. 524 p.

32. Bagnall R.S., ed. The Oxford Handbook of Papyrology. Oxford; New York, Oxford University Press, 2009. 688 p.

33. Thesaurus linguae graecae. Canon of Greek Authors and Works: TLG CD-ROM \# C. Irvine, University of California, 1999. 1 CD-ROM.

34. Trapp E. Lexikon zur byzantinischen Gräzität besonders des 9.-12. Jahrhunderts. Wien, ÖAW, 1994. 2060 p.

35. Ven P. van den. La patristique et l'hagiographie au concile de Nicée de 787. Byzantion, 1957, vol. 25, pp. 325-362.

36. Wallert A. The Reconstruction of Papyrus Manufacture: a Preliminary Investigation. Studies in Conservation, 1989, vol. 34, pp. 1-8.

37. Weitzmann K. The Monastery of St. Catherine at Mount Sinai: The Icons. From the Sixth to the Tenth Century. Princeton, Princeton University Press, 1976. $107 \mathrm{p}$.

38. Wessel K., Restle M. Reallexikon zur byzantinischen Kunst. Stuttgart, Anton Hiersemann Publ., 1971. $671 \mathrm{p}$.

\section{Information About the Author}

Kseniia S. Morugina, Senior Lecturer, Junior Researcher, Institute of World History of the Russian Academy of Sciences, Prosp. Leninskiy, 32a, 119334 Moscow, Russian Federation, ksenyamorug@mail.ru, https://orcid.org/0000-0002-6254-4244

\section{Информация об авторе}

Ксения Сергеевна Моругина, старший преподаватель, младший научный сотрудник, Институт всеобщей истории РАН, просп. Ленинский, 32а, 119334 г. Москва, Российская Федерация, ksenyamorug@mail.ru, https://orcid.org/0000-0002-6254-4244 